\title{
Chromosomal differentiation among bisexual European species of Saga (Orthoptera: Tettigoniidae: Saginae) detected by both classical and molecular methods
}

\author{
ELŻBIETA WARCHAŁOWSKA-ŚLIWA ${ }^{1}$, BEATA GRZYWACZ1, ANNA MARYAŃSKA-NADACHOWSKA ${ }^{1}$, \\ Tatjana V. KARAMYSHEVA², Nikolai B. RUBTSOV² and Dragan P. CHOBANOV ${ }^{3}$ \\ ${ }^{1}$ Institute of Systematics and Evolution of Animals, Polish Academy of Sciences, Kraków, Poland; \\ e-mail: warchalowska@isez.pan.krakow.pl \\ ${ }^{2}$ Institute of Cytology and Genetics of the Siberian Branch of the Russian Academy of Sciences, Novosibirsk, Russia \\ ${ }^{3}$ Institute of Zoology, Bulgarian Academy of Sciences, Tsar Osvoboditel 1, 1000 Sofia, Bulgaria
}

Key words. Orthoptera, Saginae, Saga, karyotype, Ag-NOR, FISH, chromosome, rDNA, telomeric repeats

\begin{abstract}
We report the karyotype characteristics including chromosome numbers of Saga campbelli campbelli, S. c. gracilis, and $S$. rammei using the following classical cytogenetic methods: C-banding, silver staining, and fluorochrome staining DAPI and CMA We also present FISH data showing the distribution of telomeric repeats and 18S rDNA on the chromosomes of these species and the results of similar studies cited in the literature on $S$. hellenica, $S$. natoliae, and $S$. rhodiensis. The five European Saga species exhibit a high rate of karyotype evolution. In addition to changes in chromosome number and morphology (by chromosomal inversion and/or chromosome fusion), interspecific autosomal differentiation involved changes in the distribution and quantity of constitutive heterochromatin and GC-rich regions, as well as the number and location of NORs. In the present study we focused on testing a hypothetical model of karyotype evolution in Saga, with particular reference to the cytogenetic mapping of rDNA and telomeric sequences. Variation in the distribution of rDNA and location of Ag-NORs are novel phylogenetic markers for the genus Saga.
\end{abstract}

\section{INTRODUCTION}

The subfamily Saginae is an ancient, highly specialized group of carnivorous bush-crickets, the ancestors of which can be traced back to the mid-Jurassic and gave rise to several groups at present occupying arid regions of the Old World, Australasia, and Central America (partim. Kaltenbach in Harz, 1969; Gorochov, 1995; etc.). The subfamily itself (sensu Eades et al., 2007; OSF online) includes 4 genera, distributed over two disjunct regions southern and southeastern Sub-Saharan Africa (3 genera) and part of the Western Palearctic (genus Saga).

The genus Saga Charpentier, 1825, comprised of 13 species, probably originated and underwent an early radiation in the Miocene of the Aegean, associated with the aridization and isolation of the area (for similar historic distributional patterns of other genera see e.g. La Greca, 1999; Ciplak, 2004). The centre of biodiversity includes Asia Minor and the Southern Balkans with most taxa having relatively restricted ranges. Nevertheless, the parthenogenetic species Saga pedo (Pallas) occurs over a territory several times larger than the total area of the ranges of all other species. In continental Europe, five species and two subspecies have been recorded so far (Kaltenbach, 1967). S. rhodiensis Salfi, although occurring on a Greek island and here also considered as "European", actually represents an element of the Mediterranean fauna of Asia Minor.

Most of the Palearctic tettigonnids of the family Tettigoniidae have a karyotype consisting of $2 n=31$ acrocentric chromosomes in the male with an $\mathrm{X} 0-\mathrm{XX}$ sex chromosome mechanism. This karyotype was suggested as ancestral for most species of this family (e.g. Hewitt, 1979; Warchałowska-Śliwa, 1998; Warchałowska-Śliwa et al., 2005). The genus Saga is characterized by extreme karyotypic diversification. A previous study carried out on this genus by Matthey (1946) revealed that $S$. cappadocica, S. ephippigera, and $S$. ornata have the ancestral karyotype $(2 \mathrm{n}=31 \delta)$. The tetraploid, parthenogenetic species $S$. pedo is characterized by the karyotype $4 n=68$ (Matthey, 1939, 1941, 1948; Goldschmidt, 1946). However, the chromosome complement of European species of Saga, based on an earlier study of $S$. hellenica, $S$. natoliae, and $S$. rhodiensis, is $2 \mathrm{n}=29 \sigma^{\star} / 30$ \% . Robertsonian centric fusion and tandem translocation are thought to be the main mechanisms responsible for the karyotypic variation observed within this group (WarchałowskaŚliwa, 1998; Warchałowska-Śliwa et al., 2007). In a previous paper, we investigated heterochromatin in three species using different staining methods, preliminary C-banding, silver impregnation (Ag-NORs), chromomycin $\mathrm{A}_{3} \quad\left(\mathrm{CMA}_{3}\right)$ and 4-6-diamidino-2-phenylindole (DAPI). $\mathrm{CMA}_{3}$ and DAPI are useful for detecting CGand AT-enriched chromosome regions, respectively. Some similarities and differences within the C-positive constitutive heterochromatin regions were found, revealing that taxonomically closely related species with the same chromosome number show different patterns of C-bands. Cytogenetic differences between these species suggest that chromosomal divergence occurred during their speciation (Warchałowska-Śliwa et al., 2007). 
Lemonnier-Darcemont et al. (2008) reached the same conclusion after studying of $S$. campbelli and $S$. rammei, which both have a chromosome number of $2 n=27 \delta$.

In this study, five species (and one subspecies) from Europe were subjected to molecular cytogenetic analyses in order to clarify the mechanism of karyotype evolution within the genus Saga. This analysis included fluorescence in situ hybridization (FISH), which revealed presence of specific DNA within chromosomes (Nath \& Johnson, 2000; Schwarzacher, 2003). Changes in the number and distribution of repetitive sequences within chromosomes provide excellent markers for chromosome evolution in many species. Ribosomal DNA (rDNA) genes are useful chromosome markers for interspecific comparative karyotyping in insects at the level of genera (Gallián et al., 1999; Martinez-Navarro et al., 2004; Zacaro et al., 2004) and population (Martinez-Navarro et al., 2004). FISH using rDNA of grasshoppers can be used on a wider range of taxa within an order (e.g. Bridle et al., 2002; Cabrero et al., 2003; Souza et al., 2003; MartinezNavarro at al., 2004; Loreto et al., 2008). Other repetitive sequences, so called telomeric DNA, are located mainly at the chromosome termini. Telomeres play an important role in maintenance of chromosomal stability and preserve genome integrity. Telomeres were used as markers for identification of chromosome ends. In the majority of insect orders, including Orthoptera, the telomeres are composed of mutliple copies of short, tandemly arranged TTAGG sequences (Okazaki et al., 1993; Sahara et al., 1999; Frydrychová \& Marec, 2002; Frydrychová et al., 2004; Vítková et al., 2005). The clusters of telomeric repeats and telomeric-like sequences were deemed useful in the identification of chromosomal rearrangements related to changes in chromosome number and evolution in insects (e.g., López-Fernández et al., 2004).

The present study reports the results of a cytogenetic analysis of $S$. campbelli campbelli, S. campbelli gracilis, and $S$. rammei using classical methods (C-banding, silver, DAPI, and $\mathrm{CMA}_{3}$ staining). In addition, FISH with $18 \mathrm{~S}$ rDNA and (TTAGG) ${ }_{n}$-specific telomeric DNA (tDNA) probes for mapping these repeats within the chromosomes were applied to these species and the results compared with those obtained previously for S. hellenica, S. natoliae and S. rhodiensis (Warchałowska-Śliwa et al., 2007). Chromosomal localization of the clusters of these repeats, along with results of routine cytogenetic techniques, gave us an insight into chromosomal evolution in the bisexual European species of the genus Saga.

\section{MATERIAL AND METHODS}

A cytogenetic analysis of the following nymphs, adult males and female bush-crickets, collected in Bulgaria and Macedonia, was undertaken: Saga campbelli campbelli Uvarov, 1921, 3 male and one female nymph and imago, Bulgaria: Maleshevska Mt., July $2006\left(41^{\circ} 43 \mathrm{~N}, 2^{\circ} 06 \mathrm{E}\right)$ leg. Chobanov D; Saga campbelli gracilis Kis, 1962, 5 male nymphs, Bulgaria: E Rodopi Mts, north of Plevoun Vill., vi.2006 (41 $\left.{ }^{\circ} 27 \mathrm{~N}, 26^{\circ} 01 \mathrm{E}\right)$, leg. Chobanov D., Warchałowska-Śliwa E.; Saga rammei Kaltenbach, 1965, 1 male, Macedonia, Bogoslovec Vill., July 2006 $\left(41^{\circ} 46 \mathrm{~N}, 22^{\circ} 01 \mathrm{E}\right)$, leg. Chobanov D. Specimens are deposited in the Institute of Systematics and Evolution of Animals, Polish Academy of Sciences (Kraków) and in the Institute of Zoology, Bulgarian Academy of Sciences (Sofia).

The testes and ovarioles were excised, incubated in a hypotonic solution $(0.9 \%$ sodium citrate), and then fixed in ethanol : acetic acid $(3: 1)$. The fixed material was squashed in $45 \%$ acetic acid. Cover slips were removed by the dry ice procedure and then the slides were air dried. The C-banding was carried out according to Sumner (1972) with a slight modification. The silver staining method for nucleolar organizer regions (NORs) was performed as previously reported (Warchałowska-Sliwa \& Maryańska-Nadachowska, 1992). In order to reveal the molecular composition of C-heterochromatin, some slides were stained with $\mathrm{CMA}_{3}$ to reveal GC enriched regions and DAPI to reveal AT enriched regions (Schweizer, 1976). Chromosomes were classified on the basis of the criteria proposed by Levan et al. (1964).

\section{DNA probe preparation}

Three different $18 \mathrm{~S}$ rDNA probes were used for the detection of rDNA sequences on chromosomes using FISH: (1) a $3.2 \mathrm{~kb}$ fragment of human 18S rDNA cloned in pHr13 (rDNA-probe) (Malygin et al., 1992), (2) and (3) about $1.8 \mathrm{~kb} 18 \mathrm{~S}$ rDNA fragment amplified from genomic DNAs of Isophya rammei (Orthoptera) and Philenus spumarius (Homoptera), respectively, using polymerase chain reaction (PCR) and primers 18Sai forward (5'-CCT GAG AAA CGG CTA CCA CAT C-3') and 18Sbi reverse (5'-GAG TCT CGT TCG TTA TCG GA-3') (Whiting et al., 1997). The PCR reactions were carried out in 25 $\mu \mathrm{l}$ reaction volumes containing $1.5 \mathrm{mM} \mathrm{MgCl}_{2}, 2.5 \mathrm{mM} \mathrm{dNTP}$, $10 \mu \mathrm{M}$ of each of the two primers, $100 \mathrm{ng}$ template DNA and 5 U Taq DNA polymerase (Qiagen, Hilden, Germany). An initial period of $3 \mathrm{~min}$ at $94^{\circ} \mathrm{C}$ was followed by 30 cycles of $60 \mathrm{~s}$ at $94^{\circ} \mathrm{C}, 60 \mathrm{~s}$ at $51^{\circ} \mathrm{C}$, and $1.5 \mathrm{~min}$ at $72^{\circ} \mathrm{C}$, and concluded by a final extension step of $10 \mathrm{~min}$ at $72^{\circ} \mathrm{C}$. Probes were labelled with biotin-11-dUTP by nick translation according to the manufacturer's instructions (Invitrogen, Tokyo, Japan).

A (TTAGG) $)_{n}$ probe, used to visualize clusters of telomeric repeats, was generated by a non-template PCR using a modified version of López-Fernández et al. (2004) technique. Briefly, PCR was carried out in a $50 \mu 1$ reaction mixture containing 1.5 $\mathrm{mM} \mathrm{MgCl} 2,0.2 \mathrm{mM}$ each dNTP, $0.5 \mu \mathrm{M}$ of each of the two primers (5'-GGTTA-GGTTA-GGTTA-GGTTA-GG-3' and 5'TAACC-TAACC-TAACC-TAACC-TAA-3') and 2 U Taq DNA polymerase. The non-template PCR was performed with an initial cycle of $90 \mathrm{~s}$ at $94^{\circ} \mathrm{C}$, followed by 30 cycles of $45 \mathrm{~s}$ at $94^{\circ} \mathrm{C}, 30 \mathrm{~s}$ at $40^{\circ} \mathrm{C}$ and $60 \mathrm{~s}$ at $72^{\circ} \mathrm{C}$, and a final extension step of $10 \mathrm{~min}$ at $72^{\circ} \mathrm{C}$. The PCR product was then labelled with digoxigenin-11-dUTP in additional PCR cycles to produce the $(\text { TTAGG })_{n}$ telomeric probe.

\section{Fluorescent in situ hybridisation}

FISH of chromosomes using the rDNA and telomeric probes was performed according to a standard protocol (Lichter et al., 1988 ) with salmon sperm DNA as the carrier DNA. Slides were treated with RNase A for $1 \mathrm{~h}$ at $37^{\circ} \mathrm{C}(100 \mu \mathrm{g} / \mathrm{ml} 2 \times \mathrm{SSC})$, rinsed in $2 \times \mathrm{SSC}$, dehydrated in an ethanol series $(70 \%, 85 \%$, $100 \%)$ and air dried. For removal of cytoplasm, the slides were incubated in pepsin $(1 \mathrm{mg} / \mathrm{ml}$ in $0.01 \mathrm{~N} \% \mathrm{HCL})$ at $37^{\circ} \mathrm{C}$ for 20 min, fixed in $1 \%$ formaldehyde in phosphate buffered saline (PBS), $50 \mathrm{mM} \mathrm{MgCl}_{2}$, dehydrated in an ethanol series $(70 \%$, $80 \%, 96 \%)$ and again air dried.

For each slide, $20 \mathrm{ng}$ of the probe mixed with $10 \mu \mathrm{g}$ of sonicated salmon sperm DNA (Invitrogen) were ethanol-precipitated, cooled to $-20^{\circ} \mathrm{C}$ and resuspended in $15 \mu \mathrm{l}$ of hybridization mix $(50 \%$ formamide, $10 \%$ dextran sulphate, $1 \%$ 


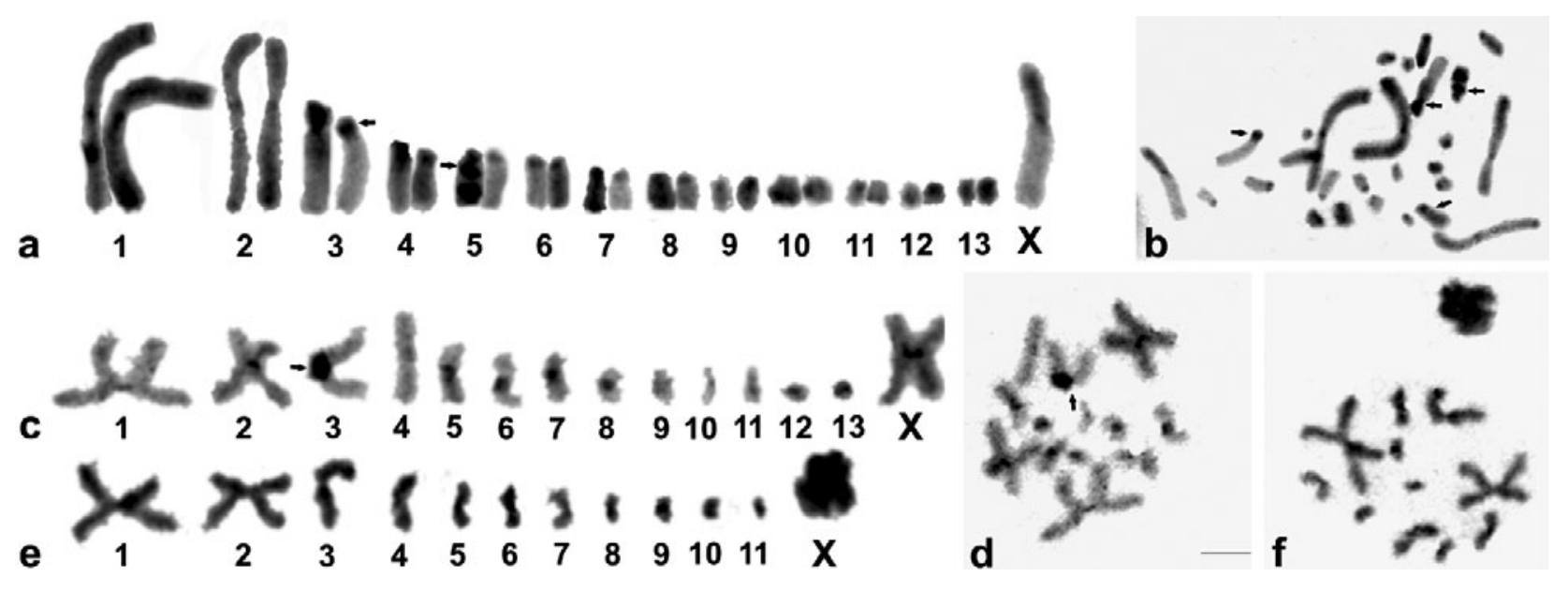

Fig. 1. C-banding staining of male chromosome complements of Saga campbelli gracilis (a-d), and S. rammei (e, f); a) S. c. gracilis - karyotype and b) spermatogonial metaphase $(2 \mathrm{n}=27)$, c) karyotype and d) metaphase II with 14 chromosomes, e) $S$. rammei - karyotype and f) metaphase II with 12 chromosomes. The arrows indicate large blocks of heterochromatin on $\mathrm{M}_{3}(\mathrm{a}-\mathrm{d})$ and an additional interstitial C-band occurring on the $\mathrm{M}_{5}$ pair $(\mathrm{a}, \mathrm{b})$ of $S$. c. gracilis. X, sex chromosome. Bar $=10 \mu \mathrm{m}$.

TABLE 1. A comparison of the distribution of heterochromatin bands, NOR and rDNA on chromosomes of the European Saga species.

\begin{tabular}{|c|c|c|c|c|c|c|c|}
\hline \multirow{2}{*}{ Species } & \multirow{2}{*}{$\begin{array}{l}\text { 2n (male), FN } \\
\text { and chromosome } \\
\text { morphology }\end{array}$} & \multirow{2}{*}{$\begin{array}{l}\text { C-bands on chromosomes } \\
\text { * intraspecific variation } \\
\text { of C-heterochromatin } \\
\text { (thick/thin or present/absent) }\end{array}$} & \multicolumn{2}{|c|}{$\begin{array}{l}\text { Position of fluorochrome } \\
\text { bands }\end{array}$} & \multirow{2}{*}{$\begin{array}{c}\text { Position of } \\
\text { NOR }\end{array}$} & \multirow{2}{*}{$\begin{array}{l}\text { rDNA } \\
\text {-FISH } \\
\text { signal }\end{array}$} & \multirow{2}{*}{ References } \\
\hline & & & bright DAPI & bright $\mathrm{CMA}_{3}$ & & & \\
\hline $\begin{array}{l}\text { S. campbelli } \\
\text { campbelli }\end{array}$ & $\begin{array}{c}27,32 \mathrm{X}, \mathrm{L}_{2} \text { subme- } \\
\text { tacentric, } \mathrm{L}_{1} \text {, meta- } \\
\text { centric, the } \\
\text { remaining autosomes } \\
\text { acrocentric }\end{array}$ & $\begin{array}{l}\text { Paracentromeric } \mathrm{L}_{1}, \mathrm{~L}_{2} \text {, } \\
\mathrm{M}_{4}-\mathrm{S}_{13}, \mathrm{X} \text { thin; } \mathrm{M}_{3} \text { thick } \\
\mathrm{S}_{8} / 9 * \text { subtelomeric } \\
\text { all } \mathrm{L}, \mathrm{M} \text { and } \mathrm{X} \text { telomeric }\end{array}$ & $\begin{array}{l}\text { Paracentro- } \\
\text { meric: } \\
\mathrm{L}_{1}, \mathrm{~L}_{2}, \mathrm{M}_{3}\end{array}$ & $\begin{array}{l}\text { Paracentro- } \\
\text { meric } \mathrm{M}_{3}, \mathrm{M}_{4} \\
\text { telomeric in } \\
\text { one arm } \mathrm{L}_{1}\end{array}$ & $\begin{array}{l}\text { Paracentro- } \\
\text { meric } \mathrm{M}_{3} \text {, } \\
\text { Subtelocen- } \\
\text { tric } \mathrm{S}_{9}{ }^{*}\end{array}$ & $\mathrm{M}_{3}$ & this study \\
\hline $\begin{array}{l}\text { S. campbelli } \\
\text { gracilis }\end{array}$ & $\begin{array}{l}27,32 \mathrm{X}, \mathrm{L}_{2} \text { subme- } \\
\text { tacentric, } \mathrm{L}_{1} \text {, meta- } \\
\text { centric, the } \\
\text { remaining autosomes } \\
\text { acrocentric }\end{array}$ & $\begin{array}{c}\text { Paracentromeric } \mathrm{L}_{1}, \mathrm{~L}_{2} \text {, } \\
\mathrm{M}_{4}-\mathrm{S}_{13}, \mathrm{X} \text { thin; } \mathrm{M}_{3} \text { thick; } \\
\mathrm{M}_{5} * \text { interstitial } \\
\mathrm{S}_{8 / 9} * \text { subtelomeric } \\
\text { all } \mathrm{L}, \mathrm{M} \text { and } \mathrm{X} \text { telomeric }\end{array}$ & $\begin{array}{c}\text { Not } \\
\text { analyzed }\end{array}$ & $\begin{array}{c}\text { Not } \\
\text { analyzed }\end{array}$ & $\begin{array}{l}\text { Paracentro- } \\
\text { meric } \mathrm{M}_{3} \\
\text { Subtelocen- } \\
\text { tric } \mathrm{S}_{9} *\end{array}$ & $\mathrm{M}_{3}$ & this study \\
\hline S. rammei & $\begin{array}{l}23,28 \mathrm{X}, \mathrm{L}_{2} \text { subme- } \\
\text { tacentric, } \mathrm{L}_{1} \text {, meta- } \\
\text { centric, the } \\
\text { remaining autosomes } \\
\text { acrocentric }\end{array}$ & $\begin{array}{c}\text { Paracentromeric: } \\
\mathrm{L}_{1}-\mathrm{M}_{8}, \mathrm{~S}_{10}, \mathrm{~S}_{11} \text { thin; } \\
\mathrm{S}_{9} \text { thick* }\end{array}$ & $\begin{array}{c}\text { Not } \\
\text { analyzed }\end{array}$ & $\mathrm{S}_{8 / 9}$ & One per cell & $\mathrm{S}_{8 / 9}$ & this study \\
\hline S. hellenica & $\begin{array}{c}29,32 \mathrm{X} \text { submeta- } \\
\text { centric, } \mathrm{L}_{1} \text { metacen- } \\
\text { tric, the remaining } \\
\text { autosomes acrocen- } \\
\text { tric }\end{array}$ & $\begin{array}{c}\text { Paracentromeric: } \mathrm{L}_{1}, \mathrm{M}_{4}-\mathrm{S}_{14} \\
\mathrm{X} \text { thin; } \mathrm{M}_{2} \text { and } \mathrm{M}_{3} \text { thick } \\
\mathrm{M}_{6} \text { interstitial } \\
\mathrm{L}_{1}, \mathrm{M}_{2}, \mathrm{M}_{3}, \mathrm{M}_{6} \text { telomeric }\end{array}$ & $\mathrm{L}_{1}, \mathrm{M}_{2}, \mathrm{M}_{6}$ & $\mathrm{~L}_{1}, \mathrm{M}_{2}, \mathrm{M}_{3}$ & $\begin{array}{c}\text { Paracentro- } \\
\text { meric } \mathrm{M}_{3}\end{array}$ & $\mathrm{M}_{3}$ & $\begin{array}{l}\text { Warchałowska } \\
\text {-Śliwa et al., } \\
2007\end{array}$ \\
\hline S. natoliae & $\begin{array}{c}29,32 \mathrm{X} \text { submeta- } \\
\text { centric, } \mathrm{L}_{1} \text { metacen- } \\
\text { tric, the remaining } \\
\text { autosomes acrocen- } \\
\text { tric }\end{array}$ & $\begin{array}{c}\text { Paracentromeric: } \mathrm{L}_{1}, \mathrm{~S}_{11}-\mathrm{S}_{14} \\
\text { thin; } \mathrm{M}_{2}-\mathrm{S}_{10}, \mathrm{X} \text { thick } \\
\mathrm{M}_{6} \text { interstitial } \\
\mathrm{L}_{1}, \mathrm{M}_{2}-\mathrm{M}_{8} \text { telomeric }\end{array}$ & $\mathrm{M}_{8 / 9}, \mathrm{X}$ & $\mathrm{M}_{8 / 9}, \mathrm{X}$ & $\begin{array}{c}\text { Paracentro- } \\
\text { meric } \mathrm{M}_{8 / 9}\end{array}$ & $\mathrm{~S}_{9}$ & $\begin{array}{c}\text { Warchałowska } \\
\text {-Śliwa et al., } \\
2007\end{array}$ \\
\hline $\begin{array}{l}S . \\
\text { rhodiensis }\end{array}$ & $\begin{array}{c}29,32 \mathrm{X} \text { submeta- } \\
\text { centric, } \mathrm{L}_{1} \text { metacen- } \\
\text { tric, the remaining } \\
\text { autosomes acrocen- } \\
\text { tric }\end{array}$ & $\begin{array}{c}\text { Paracentromeric: most of } \\
\text { autosomes and X thick, } \\
\mathrm{M}_{5}, \mathrm{M}_{6} \text { interstitial } \\
\mathrm{L}_{1}, \mathrm{M}_{2}-\mathrm{M}_{5} \text { telomeric }\end{array}$ & $\mathrm{M}_{8 / 9}, \mathrm{X}$ & $\mathrm{S}_{9}, \mathrm{X}$ & & $\mathrm{S}_{9}$ & $\begin{array}{l}\text { Warchałowska } \\
\text {-Śliwa et al., } \\
2007\end{array}$ \\
\hline
\end{tabular}

FN - fundamental number of chromosome arms; * intraspecific variation of heterochromatin; $1,2, \ldots$, the number of autosome pair; $\mathrm{X}$, sex chromosome. ${ }^{1}$ The location of $\mathrm{NOR}$ and $\mathrm{CMA}_{3}$ band on $\mathrm{M}_{6}$ pair of $S$. rhodiensis, described by Warchałowska-Śliwa et al. (2007), is incorrect. 

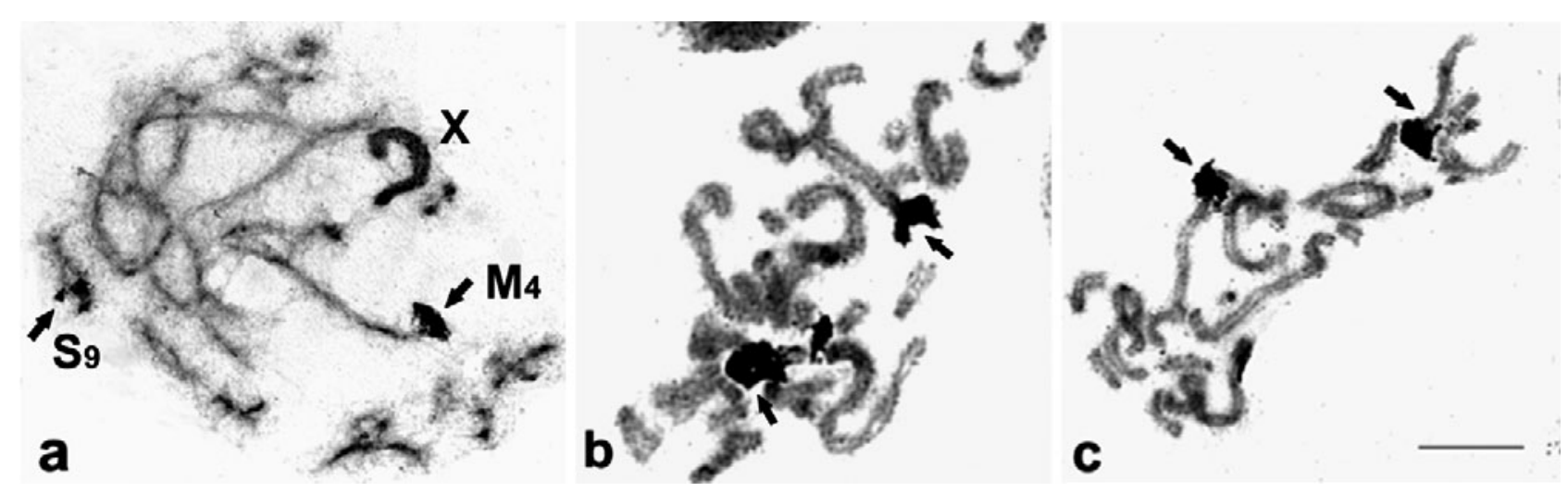

Fig. 2. Silver nitrate staining: (a) at male pachytene in S. c. campbelli and (b, c) spermatogonial prophase/metaphases in $S$. c. gracilis. NORs (arrows) were detected in the paracentromeric region of the $\mathrm{M}_{3}(\mathrm{a}, \mathrm{b})$ and in subtelocentric position of the $\mathrm{S}_{9}(\mathrm{a})$. Note a heterochromatic univalent of the sex chromosome (X). Bar $=10 \mu \mathrm{m}$.

Tween 20, $2 \times$ SSC). Metaphase spreads were denatured simultaneously with the DNA probe for $5 \mathrm{~min}$ at $75^{\circ} \mathrm{C}$. Incubation was performed overnight at $37^{\circ} \mathrm{C}$. After hybridization, slides were washed with $50 \%$ formamide in $2 \times \mathrm{SSC}(3 \times), 2 \times \mathrm{SSC}$ $(2 \times), 0.2 \times \operatorname{SSC}(1 \times)$ at $45^{\circ} \mathrm{C}$ for $5 \mathrm{~min}$. Biotin- and digoxigenin-labelled probes were visualized with avidin-Alexa 488 (Invitrogen) and mouse anti-digoxigenin antibodies conjugated to Cy3 (Sigma-Aldrich, Tokyo, Japan), respectively. Slides were counterstained with $2 \mu \mathrm{l} / \mathrm{ml}$ of DAPI (SigmaAldrich, Tokyo, Japan) for $15 \mathrm{~min}$ and then mounted in antifade solution with 1-4-diazabicyclo[2.2.2] octane (DABCO; Sigma) (see Sahara et al., 1999).

Microscopy was performed using an AxioPlan2 Imaging (Zeiss) equipped with a CCD camera (CV M300, JAI Corporation, Japan), Chroma filter sets and the ISIS5 image-processing package of MetaSystems GmbH (Altlussheim, Germany). In each experiment, at least one spermatogonial metaphase (with the exception of $S$. rammei) and 15-20 meiotic divisions (diplotene/diakinesis) were examined.

\section{RESULTS}

\section{Karyotype description based on routine staining and banding techniques}

The two subspecies of Saga campbelli: S. c. campbelli and $S$. c. gracilis have a similar karyotype, characterized by the same chromosome number, $2 \mathrm{n} \sigma^{\hat{\sigma}}=27$ and $2 \mathrm{n}+\mathrm{q}=$ 28 and congruent chromosome morphology ( $\mathrm{FN}=32$ and 34 , respectively; FN is the number of chromosome arms, including $\mathrm{X}$ chromosome). Autosomes can be divided into three size groups: two large metacentric $\left(\mathrm{L}_{1}\right)$ and submetacentric $\left(\mathrm{L}_{2}\right)$ pairs, six medium sized pairs $\left(\mathrm{M}_{3}-\mathrm{M}_{8}\right)$ and five small acrocentric pairs $\left(\mathrm{S}_{9}-\mathrm{S}_{13}\right)$ (Fig. 1a-d). In $S$. rammei, the complement is reduced to $2 \mathrm{n} \hat{\sigma}=23$ and $2 \mathrm{n}$ ㅇ $=24(\mathrm{FN}=28$ and 30 , respectively). For this species we examined five diakinesis and eight metaphase II. In this case the bivalents may be classified according to size into two large metacentric $\left(\mathrm{L}_{1}\right)$ and submetacentric $\left(\mathrm{L}_{2}\right)$ pairs, five medium sized $\left(\mathrm{M}_{3}-\mathrm{M}_{7}\right)$ acrocentric pairs and four small $\left(\mathrm{S}_{8}-\mathrm{S}_{11}\right)$ acrocentric pairs (Fig. 1e, f). In both species the submetacentric $\mathrm{X}$ chromosome is the largest in the set. These species show the $\mathrm{X} 0{ }^{\hat{}}$ and $\mathrm{XX}+9$ type of chromosome sex determination.

In Table 1, a comparison of the C-banding patterns, Ag-NOR localization, and fluorochrome banding patterns
(DAPI and $\mathrm{CMA}_{3}$ ) of chromosomes of these species and the results of a former study (Warchałowska-Śliwa et al., 2007) are shown.

C-banding of spermatogonial mitotic metaphase and meiotic cells of both subspecies of $S$. campbelli and of $S$. rammei revealed constitutive heterochromatin blocks (thin C-bands) in the paracentromeric region of most of the chromosomal elements, with the exception of $\mathrm{M}_{3}$ in $S$. c. campbelli and S. c. gracilis. In this case, C-bands occupied the region next to the centromere (thick C-bands) (Fig. 1a, b). Additionally, in $S$. campbelli, a subtelomeric C-band occurs on the $\mathrm{S}_{8}$ or $\mathrm{S}_{9}\left(\mathrm{~S}_{8 / 9}\right)$ pair. Constitutive heterochromatin polymorphism involving interstitial C-bands on $\mathrm{M}_{5}$ was noted in one out of three individuals of $S$. c. gracilis (Fig. 1a, b). Paracentromeric C-bands on $\mathrm{S}_{9}$ were observed in an individual of $S$. rammei. Telomeric C-bands in $S$. campbelli, if present, are located in large and medium sized chromosomes, and in both arms of X.

$\mathrm{AgNO}_{3}$ staining revealed the presence of two active NORs in the paracentromeric region of $\mathrm{M}_{3}$ and a small NOR with a subtelocentric position on $\mathrm{S}_{9}$ in both subspecies of $S$. campbelli (Fig. 2a, b). The latter is probably a "secondary NOR" carrying a small nucleolus seen only in some of the cells (Fig. 2c). In S. rammei, an NOR was revealed but not localized in diplotene in the studied cells, though in an early prophase cell one active NOR was observed. A previous description of the NOR-location in S. rhodiensis (Warchałowska-Śliwa et al., 2007) was incorrect because the nuclear remnants were associated with the $\mathrm{S}_{8 / 9}$ bivalent (not $\mathrm{M}_{6}$ ), because the determination of this particular pair of autosomes was wrong.

Bright DAPI signals in $\mathrm{L}_{1}, \mathrm{~L}_{2}$, and $\mathrm{M}_{3}$ of both subspecies of $S$. campbelli were observed in the paracentromeric region, clearly associated with C-bands (not shown). $\mathrm{CMA}_{3}$ staining (not shown) of the male spermatogonial mitotic metaphase and meiotic cells in S. c. campbelli produced positive fluorescence signals on $\mathrm{L}_{1}$, only in one arm, $\mathrm{M}_{3}$ and $\mathrm{M}_{4}$. However, a $\mathrm{CMA}_{3}$-positive region was coincident with the active $\mathrm{NOR}$ visualized by $\mathrm{Ag}-\mathrm{NO}_{3}$ staining only on $\mathrm{M}_{3}$. The NOR associated with the C-positive region of $\mathrm{M}_{3}$ was formed by two proximate 
regions of different structure: one positive band after DAPI and another after $\mathrm{CMA}_{3}$ (not shown). Unfortunately, we were not able to conclusively confirm these positions in $S$. c. gracilis due to a low number of goodquality chromosome spreads. The results of DAPI and $\mathrm{CMA}_{3}$ staining are summarized in Table 1.

\section{Localization of rDNA and tDNA clusters}

Hybridization with three different rDNA probes always produced the same results, i.e. their hybridization signals could not be distinguished from one another and resulted in the same signal on spermatogonial mitotic and meiotic chromosomes. Two colour FISH with two differently labelled probes, the Alexa 488-labelled 18S rDNA probe and Cy3-labelled (TTAGG) ${ }_{n}$ probe, was performed in order to analyze the distribution of ribosomal and telomeric DNA on chromosomes of five species and one subspecies of the genus Saga. FISH revealed one cluster of rDNA, located on the autosomes of all species/subspecies (Table 1 and Fig. 3a-h). Their locations were observed at mitotic metaphases or on bivalents from diakinesis to metaphase I in the paracentromeric regions of the acrocentric chromosome $\mathrm{M}_{3}$ of both subspecies of $S$. campbelli and $S$. hellenica (Fig. $3 \mathrm{a}-\mathrm{d}$ ), and also on a small chromosome, probably $\mathrm{S}_{8 / 9}$, of $S$. rammei, $S$. natoliae, and S. rhodiensis (Fig. 3e-g). In all five species analyzed, FISH signals were coincident with the active NORs visualized by Ag-NOR staining. However, in both subspecies of $S$. campbelli, two NORs were observed on $\mathrm{M}_{3}$ (cluster of labelled rDNA) and $\mathrm{S}_{8 / 9}$ (low activity rDNA cluster in the subtelocentric region). However, FISH revealed rDNA presence only on $\mathrm{M}_{3}$, so that the NOR activity on $\mathrm{S}_{8 / 9}$ is most likely due to only a few rDNA genes, i.e. less than the minimum number detectable by FISH (Cabrero \& Camacho, 2008). The observed rDNA-FISH signal on $\mathrm{S}_{8 / 9}$ of the three species varied in size (Fig. 3e-g), suggesting the occurrence of polymorphism in copy number of rDNA sequences.

FISH, using the (TTAGG) ${ }_{n}$ probe, of spermatogonial mitoses and spermatocyte nuclei at different stages of meiosis was performed on all Saga species. On most chromosomes of all species, the FISH signal was detected at the distal ends of each autosome. Differences in the intensity of the hybridization signal were detected among most of the autosomes of each species, and in the X chromosome of some of them (Fig. 3a-h). Generally, the tDNA-FISH signals on chromosomes of $S$. natoliae and $S$. hellenica were smaller than those observed in other species. No tDNA-FISH signals were found in the centromeric region of metacentric/submetacentric chromosomes (Fig. 3a-h). Heterogeneity of the tDNA-FISH signals on the $\mathrm{X}$ chromosome was detected in all species.

\section{DISCUSSION}

The karyotype of bisexual species of the genus Saga differs extensively from the ancestral karyotype in terms of chromosome number and morphology, brought about by inversion of chromosomal regions and/or fusion of chromosomes in modern species. The ancestral chromosome number of $2 \mathrm{n}=31(\mathrm{FN}=31)$ is recorded in the male of S. cappadocica (Matthey, 1949), S. ornata (Matthey, 1946, 1948; Goldschmidt, 1946), S. gracilipes, and S. ephippigera (Matthey, 1946, 1948; Goldschmidt, 1946). Three European species, i.e. S. hellenica, S. natoliae, and $S$. rhodiensis, have a reduced chromosome number of $2 \mathrm{n}=29(\mathrm{FN}=32)$. The latter karyotype is as a result of one Robertsonian translocation (metacentric $\mathrm{L}_{1}$ pair) and one pericentric inversion in the $\mathrm{X}$ chromosome (Warchałowska-Śliwa et al., 2007). For both subspecies of $S$. campbelli it is hypothesized that two Robertsonian translocations and one pericentric inversion, resulted in $2 \mathrm{n}=27(\mathrm{FN}=32)\left(\right.$ two metacentric/submetacentric $\mathrm{L}_{1}, \mathrm{~L}_{2}$ pairs and a subacrocentric $\mathrm{X}$ chromosome). The chromosome number of $S$. campbelli accords with the number recently reported by Lemonnier-Darcemont et al. (2008). However, in our study an unexpected chromosome number of $2 \mathrm{n}=23$ was revealed in $S$. rammei. Lemonnier-Darcemont et al. (2008) describe $S$. rammei as having $2 n=27$. Our data indicate a tendency for a further reduction in chromosome number in this taxon. As mentioned above, two Robertsonian fusions and a pericentric inversion in the $\mathrm{X}$ were involved in the reorganization of the karyotype. The mechanism that led to the further reduction in the diploid chromosome number remains unclear. Such a significant difference in the chromosome number for a single species, bearing in mind the karyotype variation in the genus, cannot exclude the possibility that the specimens we studied and those studied by Lemonnier-Darcemont et al. (2008) belong to two different species. These differences may be caused too by inter-species hybridization or population polymorphism, but this remains to be resolved and additional samples from Macedonia need to be analyzed. Although this exceptionally low chromosome number is uncommon, it does occur within a few groups of Tettigoniidae (see Warchałowska-Śliwa, 1998). It should also be emphasized that the ancestor of the tetraploid, parthenogenetic species $S$. pedo, with $4 \mathrm{n}=68$ (Matthey, 1948; Goldschmidt, 1946; Cabrero et al., 2007), may be related to S. ephippigera (Warchałowska-Śliwa et al., 2007). Within the latter species (with $2 \mathrm{n}=31$ ) some individuals possessed a supernumerary pair of chromosomes $(2 \mathrm{n}=$ 33 ). The occurrence of supernumerary chromosomes (B) has been previously noted in S. hellenica (WarchałowskaŚliwa et al., 2007).

Chromosome structure in Orthoptera has been thoroughly analyzed using the C-banding technique and NOR Ag-staining, including comparative studies of populations, species, and genera (e.g. Camacho et al., 1987; Warchałowska-Śliwa et al., 2005). Five species of the genus Saga revealed discrete differences not only in the amount of heterochromatin but also in the number of C-positive bands and their locations. S. natoliae, $S$. rhodienis, $S$. campbelli, and $S$. rammei showed similar C-banding patterns; $S$. hellenica exhibited a different pattern (Table 1). Interspecific polymorphism mainly associated with variable numbers of additional $\mathrm{C}$-positive bands (indicated in Table 1 by an asterisk) was detected in some species of tettigonids (e.g. Warchałowska-Śliwa et al., 

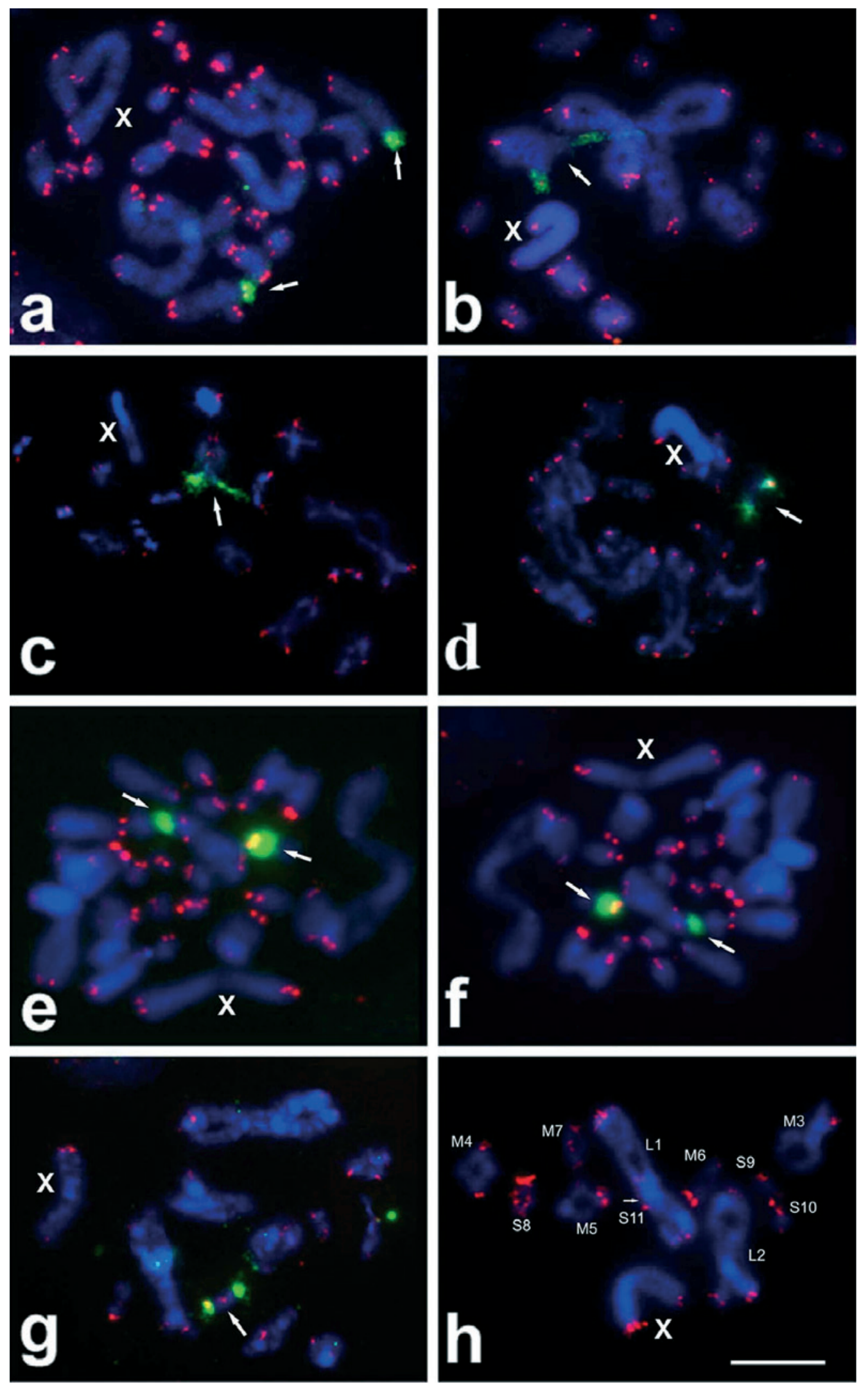

Fig. 3. FISH on male chromosomes of five species of Saga using both the $18 \mathrm{~S}$ rDNA (green) and telomeric DNA (red) probes (a-g) or only the telomeric DNA probe (h). (a) Mitotic metaphase in S. c. campbelli; (b) diakinesis in S. c. campbelli; (c) diplotene in $S$. hellenica; (d) diplotene in S. natoliae; (e, f) mitotic metaphase in S. rhodiensis; (g, h) diplotene in S. rammei. Arrows indicate rDNA sites in paracentromeric regions of the acrocentric chromosome $\mathrm{M}_{3}$ of $S$. campbelli and $S$. hellenica $(\mathrm{a}-\mathrm{c})$ and on a small chromosome (probably $\mathrm{S}_{9}$ ) of $S$. rammei, $S$. natoliae, and $S$. rhodiensis $(\mathrm{d}-\mathrm{g})$. Hybridization areas on $\mathrm{S}_{8 / 9}$ of these three species often varied in size between two homologous chromosomes $(\mathrm{e}-\mathrm{f}) . \mathrm{X}-$ sex chromosome. Bar $=10 \mu \mathrm{m}$. 
1992). The number of NORs and their locations are good markers for discriminating between related species of grasshoppers (e.g. Cabrero \& Camacho, 1986; Rocha et al., 2004) and within Tettigonioidea (WarchałowskaŚliwa \& Maryańska-Nadachowska, 1992: WarchałowskaŚliwa et al., 1992, 1994, 2005). The karyotypes of five Saga species described in this paper and an earlier study (Warchałowska-Śliwa et al., 2007) have NORs on two different chromosomes. In S. hellenica a single NOR occurs on the medium-sized bivalent $\mathrm{M}_{3}$, whereas in $\mathrm{S}$. campbelli two NORs were observed on $\mathrm{M}_{3}$ and $\mathrm{S}_{8 / 9}$. In contrast to these species, the only NORs in the karyotypes of $S$. natoliae, $S$. rhodiensis, and $S$. rammei, were associated with a small chromosome ( $\mathrm{S}_{8 / 9}$ according to size). Thus, this marker can successfully be used in the analysis of chromosomal stability within this group.

In species of the genus Saga, regions consisting of GCor AT enriched DNA were visualized with the basespecific fluorochromes DAPI and $\mathrm{CMA}_{3}$, respectively. NORs were associated with coincident $\mathrm{C}$ - and $\mathrm{CMA}_{3}-$ positive bands. However, the $\mathrm{CMA}_{3}$ fluorochrome also revealed chromosomal regions that were not detected by silver impregnation (see Table 1 and WarchałowskaŚliwa et al., 2007). The data showed that C-positive regions had heterogeneous DNA sequences, i.e. not all were exclusively AT- or GC-rich. Furthermore, in the species investigated, the $\mathrm{CMA}_{3}$ fluorochrome, as in other species, did not detect all NORs, (Vitturi et al., 1999, 2003; Colomba et al., 2004; Schneider et al., 2006).

Silver staining was used to evaluate the activity of rDNA clusters. We detected variation in the pattern of rDNA loci in the genus Saga. S. campbelli and S. hellenica (with different chromosome numbers), which have a $\mathrm{M}_{3}$ autosomal pair with ribosomal loci, whereas in $S$. rammei, S. natoliae, and $S$. rhodiensis a small-sized $\mathrm{S}_{9}$ bivalent (probably homologous in these species) showed a FISH signal. In some species with rDNA loci located on $\mathrm{M}_{3}$ and $\mathrm{S}_{9}$ autosomes, the size of the positive FISH fluorescent signals varies between homologous arms (Fig. $3 \mathrm{e}-\mathrm{f})$. The existence of the secondary NOR, carrying a small nucleolus in some cells in $S$. campbelli (located in $\mathrm{S}_{8 / 9}$ ), might indicate that this NOR is either a new NOR (i.e., a part of rDNA copies moved to new locations) or it represents remnants of a nucleolus in the process of being eliminated (Cabrero \& Camacho, 2008). Additionally, FISH analyses indicate a cluster of $18 \mathrm{~S}$ rDNA repeats coincident with telomeric repeats at the end of chromosomes with active NORs, so the rDNA cluster is probably located near telomeres, in a subtelomeric region.

The (TTAGG) $)_{n}$ sequence is found at chromosome ends in most arthropod clades, which supports the hypothesis that this is an ancestral sequence for telomere DNA in insects (Frydrychová et al., 2004; Vítková et al., 2005). To date these telomeric repeats have been reported in several species of Orthoptera such as the camel cricket Diestrammena japonica, locust Locusta migratoria, some grasshoppers and Taiwanese cricket Teleogryllus taiwanemma (Okazaki et al., 1993; López-León et al., 1999; Sahara et al., 1999; Kojima et al., 2002; López-Fernández et al., 2004; Vitturi et al., 2008). In this study we detected the "insect-type" telomeric sequence at the ends most of the chromosomes of European species of Saga. At the end of one arm of the X chromosome of $S$. natoliae and $S$. hellenica, the telomeric probe did not give a visible signal. Similar heterogeneity is recorded in the parthenogenetic $S$. pedo (Cabrero et al., 2007). The weak signal at the ends of the Saga chromosome arms could be due to low copy number of the telomeric repeats, too low for the detection by standard FISH techniques. Nevertheless, our results clearly demonstrate that the telomeric regions of autosomes and the submetacentric $\mathrm{X}$ chromosome are composed of the (TTAGG) ${ }_{n}$ telomeric repeats typical of Orthoptera (López-Fernández et al., 2004).

The chromosomal characters discussed above may be partly considered as synapomorphies and characteristic of some groupings of possibly closely related species (Warchałowska-Śliwa et al., 2007). Though generally controversial, the characters investigated support a closer relationship between some taxa (e.g. S. natoliae and $S$. rhodiensis), while the position of others remain unclear. Based on the most conservative arguments, supported by the chromosome number, the following groups are suggested: (A) S. ehippigera, S. ornata, and S. cappadocica; (B) S. natoliae, S. rhodiensis, and S. hellenica; (C) $S$. campbelli; (D) S. rammei; (E) S. pedo. These relationships or differences are supported by their amplitudetemporal song structure, which has a very important role in sexual signalling duing mating (e.g. Heller, 1988; Warchałowska-Śliwa et al., 2007). The S. natoliae group is quite well defined by its song, consisting of long constant sequences of syllable groups (echemes), in which echemes are separated by intervals of several seconds. Within this group the song of $S$. hellenica differs in its fine syllable-structure, which is similar to that of $S$. campbelli (cf. Heller, 1988; Kolics et al., 2008). The song of $S$. rammei has shorter and more frequently repeated echemes (Kolics et al., 2008), thus it is somewhat transitional to the fast echeme repetitive song of $S$. ephippigera (D.P. Chobanov, unpubl. data; see also Warchałowska-Śliwa et al., 2007). However, this grouping is not well supported by morphology. On the basis of morphological characters, Kaltenbach (1967) outlines four groups of species within the genus Saga, which include the following: (A) S. natoliae, S. rhodiensis, S. ehippigera; (B) S. cappadocica, S. campbelli, S. rammei, S. hellenica; (C) S. ornata; (D) S. pedo. This classification needs to be revised taking into account not only the new data on chromosome characteristics but also a reconsideration of the morphological characters. One interesting point concerns the position of $S$. pedo. Though it is always ignored because of its unique parthenogenesis and tetraploidy, the question of its phylogenetic affinities persists. Morphology supports its close relationship with $S$. campbelli, while the chromosome set of $S$. pedo could be derived from that of $S$. ephippigera. It is worth mentioning that these are the northernmost distributed species and both $S$. campbelli and S. ephippigera are amongst the 
few species that probably occur para- or syntopically with S. pedo.

In conclusion, the chromosomal analysis of five European Saga species suggests a high rate of karyotype evolution in these species. Besides changes in chromosome number and morphology (by chromosomal inversion and/or probably fusion), interspecific autosomal differentiation has involved the distribution and quantity of constitutive heterochromatin and GC- rich regions, as well as the number and location of NORs. The present study focused on testing the model of evolution in Saga, with particular reference to the cytogenetic mapping of rRNA coding genes and telomeric sequences, performed for the first time in tettigonids. Variation in the distribution of rDNA and/or Ag-NORs show the importance of these patterns as phylogenetic markers in the genus Saga. Future karyotype analyses using FISH with telomeric and rRNA genes should be carried out on more populations and individuals in order to gain a more comprehensive view of the chromosome evolution in this group. Combined interdisciplinary investigations (especially including DNA-sequencing) on larger samples would be helpful in revealing the phylogenetic relationships within Saga and the evolutionary history of this intriguing group.

ACKNOWLEDGEMENTS. This work was partially supported by grants to T. Karamysheva from RFBR no. 08-04-00167, the Mianowski Fund, and a project between the Russian Academy of Sciences and the Polish Academy of Sciences.

\section{REFERENCES}

Bridle J.R., de la Torre J., Bella J.L., Butlin R.K. \& Gosálvez J. 2002: Low level of chromosomal differentation between the grasshoppers Chorthippus brunneus and Chorthippus jacobsi (Orthoptera; Acrididae) in northen Spain. Genetica 114: 121-127.

Cabrero J., Bugrov A., Warchalowska-Śliwa E., López-León M.D., Perfectti F. \& Camacho J.PM. 2003: Comparative FISH analysis in five species of Eyprepocnemidine grasshoppers. Heredity 90: 377-381.

Cabrero J. \& Camacho J.P.M. 1986: Cytogenetics studies in gomphocerine grasshopper. I. Comparative analysis of chromosome C-banding pattern. Heredity 56: 365-372.

CABrero J. \& CAMACho J.P.M. 2008: Location and expresion of ribosomal RNA genes in grasshoppers: Abundance of silent and cryptic loci. Chromosome Res. 16: 595-607.

Cabrero J., Gómez R. \& Camacho J.P.M. 2007: No evidence of the presence of Wolbachia in the parthenogenetic insect Saga pedo. Proc. XI. Eur. Soc. Evol. Biol. Congress, Uppsala, Sweden, 20-25 August 2007. Uppsala, p. 277.

Camacho J.PM., Pascual F., Belda J. \& Cabrero J. 1987: Cytological markers for analyzing evolutionary relationship between related species of orthopteroids. In Baccetti B. (ed.): Evolutionary Biology of Orthopteroid Insects. Ellis Horwood, Chichester, pp. 148-156.

CIPLAK B. 2004: Biogeography of Anatolia: the marker group Orthoptera. Mem. Soc. Entomol. Ital. 82: 357-372.

Colomba M., Vitturi R., Volpe N., Lannino A. \& Zunino M. 2004: Karyotype, banding and rDNA FISH in the scarab beetle Anoplotrupes stercorosus (Coleoptera: Scarabaeoidae: Geotrupidae. Description and comparative analysis. Micron 35: $717-720$.
Eades D.C., Otte D. \& Naskrecki P. 2007: Orthoptera Species File Online. Version 2.0/3.0 http://Orthoptera.SpeciesFile.org $(10 / 05 / 2007)$

FrYDRYCHOVÁ R. \& MAREC F. 2002: Repeated losses of TTAGG telomere repeats in evolution of beetles (Coleoptera). Genetica 115: 179-187.

Frydrychová R., Grossmann P., Trubač P, Vítková M. \& MAREC F. 2004: Phylogenetic distribution of TTAGG telomeric repeats in insects. Genome 47: 163-178.

Galián J., Rúa P., Serrano J., Juan C. \& Hewitt G.M. 1999: Phylogenetic relationship in the west Mediterranean Scartina (Coleoptera: Carabidae) inferred from mitochondrial COI sequence and karyotype analysis. J. Zool. Syst. Evol. Res. 37: 85-92.

Goldschmidt E. 1946: Poliploidy and parthenogenesis in the genus Saga. Nature 158: 587-588.

Gorochov A. 1995: System and Evolution of the Suborder Ensifera (Orthoptera). Part II. Proceedings of the Zoological Institute 260. Russian Academy of Sciences, St. Petersburg, $223 \mathrm{pp}$.

Harz K. 1969: Die Orthopteren Europas I. Series Entomol 5. Dr W Junk, The Hague, 776 pp.

HELler K.-G. 1988: Bioakustik der europäischen Laubheuschreken. Josef Margraf, Weikersheim, 358 pp.

HewitT G.M. 1979: Grasshoppers and Crickets. Animal Cytogenetics, 3. Insecta I. Orthoptera. Borntraeger, Berlin, Stuttgart, $170 \mathrm{pp}$.

Kaltenbach A. 1967: Unterlagen für eine Monographie der Saginae I. Superrevision der Gattung Saga Charpentier (Saltatoria: Tettigoniidae). Beitr. Entomol. 17: 3-107.

Kojima K.K., Kubo Y. \& Fujiwara H. 2002: Complex and tandem repeat structure of subtelomeric regions in the Taiwan cricket, Teleogryllus taiwanemma. J. Mol. Evol. 54: 474-485.

Kolics B., Orci K.M., Chobanov D., Baska F., Kondorosy E. \& MülleR T. 2008: Description of the song of the bushcricket Saga rammei Kaltenbach, 1965 (Orthoptera: Tettigoniidae). Biologia (Zool.) 63: 1-7.

LA GRECA M. 1999: Il contributo degli Ortotteri (Insecta) alla conoscenza della biogeografia dell'Anatolia: la componente gondwaniana. Biogeographia 20: 179-200.

Lemonnier-Darcemont M., Dutrillaux A.M., Dutrillaux B. \& DARCEMONT C. 2008: Recherches sur la phylogènie du genre Saga (Orthoptera: Tettigoniidae) données chromosomiques. Ann. Soc. Entomol. Fr. 44 : 477-485.

Levan A., Fredga K. \& Sandberg A.A. 1964: Nomenclature for centromeric position of chromosomes. Hereditas 52: 201-220.

Lichter P., Cremer T., Tang C.J., Watkins P.C., Manuelidis L. \& WARD D.C. 1988: Rapid detection of human chromosome 21 aberration by in situ hybridisation. Proc. Natl. Acad. Sci. USA 85: 9664-9668.

lópez-Fernández C., Pradillo E., Zabal-Aguirre M., Fernández J.L., Garcia de la Vega C. \& Gisálvez J. 2004: Telomeric and interstitial telomeric-like DNA sequence in Orthoptera genomes. Genome 47: 757-763.

López-León M.D., CABrero J. \& CAMACho J.P.M. 1999: Unusually high amount of inactive ribosomal DNA in the grasshopper Stauroderis scalaris. Chromosome Res. 7: 83-88.

Loreto V., Cabrero J., López-León M.D., Camacho J.P.M. \& SouzA M.J. 2008: Comparative analysis of rDNA location in five Neotropical gomphocerine grasshopper species. Genetica 132: 95-101.

Malygin A.A., Graifer D.M., Zenkova M.A., Mamaev S.V. \& KARPOVA G.G. 1992: Affinity modification of 80S ribosomes from human placenta by derivatives of tri- and hexauridylates as mRNA analogs. Mol. Biol. (Moscow) 26: 142-149. 
Matthey R. 1939: La formule chromosomiale de la sauterelle parthénogénétique Saga serrata Fabr. et de l'Ephippigera vitium. C. R. Soc. Biol. Paris 132: 369-370.

Matthey R. 1941: Etude biologique et cytologique de Saga pedo Pallas (Orthoptera - Tettigoniidae). Rev. Suisse Zool. 48: $91-102$.

Matthey R. 1946: Démonstration du caractère géographique de la parthénogenèse de Saga pedo Pallas et de la polyploidie, par comparaison avec les espèces bisexueles $\mathrm{S}$. ephippigera Fisch. et S. gracilipes Uvar. Experientia 2: 260-261.

Matthey R. 1948: A propos de la polyploidie de Saga pedo Pallas (Orthoptera - Tettigoniidae). Experientia 4: 26-27.

Matthey R. 1949: Les chromosomes de Saga cappadocica Werner (Orthoptera, Tettigoniidae). Arch. J. Klaus Stift. Vererbf. 25: 44-46.

Martinez-Navarro E.M., Serrano J. \& Galián J. 2004: Chromosome evolution in ground beetles: localization of the rDNA loci in the tribe Harpalini (Coleoptera, Carabidae). $J$. Zool. Dyst. Evol. Res. 42: 38-43.

NATH J. \& Johnson K.L. 2000: A review of fluorescence in situ hybridization (FISH): current status and future prospects. Biotechn. Histochem. 75: 54-78.

Okazaki S., Tsuchida K., Maekawa H., Ishikawa H. \& FujiWARA H. 1993: Identification of a pentanucleotide telomeric sequence, $(\text { TTAGG })_{n}$ in the silkworm Bombyx mori and in other insects. Mol. Cell. Biol. 13: 1424-1432.

Rocha M.F., Souza M.J. \& Moura R.C. 2004: Karyotyic analysis, contitutive heterochromatin and NOR distribution in five grasshopper species of the subfamily Leptysminae (Acrididae). Caryologia 57: 107-116.

Sahara K., Marec F. \& Traut W. 1999: TTAGG telomeric repeats in chromosomes of some insects and other arthropods. Chromosome Res. 7: 449-460.

Schneider M.C., Almeida M.C., Rosa S.P., Costa C. \& Cella D.M. 2006: Evolutionary chromosomal differentiation among four species of Conoderus Eschschltz, 1829 (Coleoptera, Elateridae, Agrypninae, Conoderini) detected by standard staining, C-banding, silver nitrate impregnation, and $\mathrm{CMA}_{3} / \mathrm{DA} / \mathrm{DAPI}$ staining. Genetica 128: 333-346.

SCHWARZACHER T. 2003: DNA, chromosomes, and in-situ hybridization. Genome 46: 953-962.

SCHWEIZER D. 1976: Reverse fluorescent chromosome banding with chromomycin and DAPI. Chromosoma 58: 307-324.

Souza M.J. \& Haver P.R.O. \& Melo N.F 2003: Karyotype, $\mathrm{C}$-and fluorochrome banding patterns, NOR location and FISH in the grasshoppers Xestotrachelus robustus (Romelidae). Caryologia 56: 261-267.

SUMNER S.G. 1972: A simple technique for demonstrating centromere heterochromatin. Exp. Cell. Res .75: 304-306.

Vítková M., Traut W.T., Zrzavý J. \& Marec F. 2005: The evolutionary origin of insect telomeric repeats, (TTAGG) Chromosome Res. 13: 145-156.
Vitturi R., Colomba M.S., Barbier R. \& Zunino M. 1999: Ribosomal DNA location in the scarab beetle Thorectes intermedius (Costa) (Coleoptera: Geotruidae) using banding and fluorescent in situ hybridization. Chromosome Res. 7: 255-260.

Vitturi R., Colomba M., Volpe N., Lannino A. \& Zunino M. 2003: Evidence for male X0 sex-chromosome system in Pentodon bidens punctatum (Coleoptera: Scarabaeoidea: Scarabaeidae) with X-linked 18S-28SrDNA cluster. Genes Genet. Syst. 78: 427-432.

Vitturi R., Lannino A., Mansueto C., Mansueto V. \& Colomba M. 2008: Silver-negative NORs in Pamphagus ortolaniae (Orthoptera: Pamphagidae). Eur. J. Entomol. 105: 35-39.

WARCHAŁOWSKA-ŚLIWA E. 1998: Karyotype characteristics of katydid orthopterans (Ensifera, Tettigoniidae) and remarks on their evolution at different taxonomic levels. Folia Biol. (Kraków) 46: 143-176.

WarchalowSKA-Śliwa E. \& MaryaŃSKa-NadachowsKa A. 1992: Karyotypes, C-bands, NORs location in spermatogenesis of Isophya brevipennis Brunner (Orthoptera: Phaneropteridae). Caryologia 45: 83-89.

WarchalowsKa-Śliwa E., MaryańSKa-NadachowsKa A. \& Bugrov A.G. 1992: Karyotypes, C-heterochromatin, and NOR in three species of the genus Gampsocleis Fieb. (Orthoptera: Tettigonioidea: Decticinae). Folia Biol. (Kraków) 40: 119-127.

WarchalowsKa-Śliwa E., Bugrov A.G. \& MaryańSKaNaDACHOWSKA A. 1994: Karyotypes, C-banding pattern, and NORs of the genus Montana Zeuner 1941 (Orthoptera, Tettigonioidea, Decticinae). Folia Biol. (Kraków) 42: 89-94.

WarchalowsKa-Śliwa E., Heller K.-G. \& MaryańsKaNADACHOWSKA A. 2005: Cytogenetic variability of European Tettigoniinae (Orthoptera, Tettigoniidae): Karyotypes, C-and Ag-NOR-banding. Folia Biol. (Kraków) 53: 161-171.

Warchalowska-Śliwa E., MaryańsKa-NadachowsKa A. \& Heller K.-G. 2007: Cytogenetic variability of the genus Saga Charp. (Orthoptera, Tettigoniidae, Saginae): Heterochromatin distribution. Caryologia 60: 29-36.

Whiting M.F., Carpenter J.C., Wheeler Q.D. \& Wheeler W. C. 1997: The Strepsiptera problem: phylogeny of the holometabolous insect orders inferred from $18 \mathrm{~S}$ and $28 \mathrm{~S}$ ribosomal DNA sequences and morphology. System. Biol. 46: 1-68.

Zacaro A.A., Proença S.J.R., Lopez-Andrade C. \& Serrano A.R.M. 2004: Cytogenetic analysis of Ctenostomini by C-banding and rDNA localization and its relevance to the knowledge of the evolution of tiger beetles (Coleoptera: Cicindelidae). Genetica 122: 261-268.

Received July 4, 2008; revised and accepted September 1, 2008 